\title{
Genetic and phenotypic multi-character approach applied to multivariate models for wheat industrial quality analysis
}

\author{
V.J. Szareski ${ }^{1}$, I.R. Carvalho ${ }^{1}$, K. Kehl ${ }^{2}$, A.M. Levien ${ }^{2}$, F. Lautenchleger ${ }^{3}$, \\ M.H. Barbosa ${ }^{1}$, G.G. Conte ${ }^{1}$, M. Peter ${ }^{1}$, A.B.N. Martins ${ }^{1}$, F.A. Villela ${ }^{1}$, \\ V.Q. de Souza ${ }^{4}$, L.C. Gutkoski ${ }^{5}$, T. Pedó ${ }^{1}$ and T.Z. Aumonde ${ }^{1}$ \\ ${ }^{1}$ Universidade Federal de Pelotas, Capão do Leão, RS, Brasil \\ ${ }^{2}$ Fundação Pró-sementes, Passo Fundo, RS, Brasil \\ ${ }^{3}$ Universidade Estadual Centro-Oeste, Guarapuava, PR, Brasil \\ ${ }^{4}$ Universidade Federal do Pampa, São Gabriel, RS, Brasil \\ ${ }^{5}$ Universidade Federal de Passo Fundo, Passo Fundo, RS, Brasil \\ Corresponding author: I.R. Carvalho \\ E-mail: carvalho.irc@gmail.com
}

Genet. Mol. Res. 18 (3): gmr18223

Received November 27, 2018

Accepted July 15, 2019

Published July 22, 2019

DOI http://dx.doi.org/10.4238/gmr18223

ABSTRACT. We appled a genetic and phenotypic multi-character predicted approach to the use of the multivariate methods Additive Main effects and Multiplicative Interaction (AMMI) and Genotype Main Effects and Genotype Environment Interaction (GGE). The experiment was carried out in the agricultural crop year of 2016 in the state of Rio Grande do Sul, Brazil. The experimental design was a randomized block design, with 14 growing environments $\mathrm{x}$ five wheat genotypes arranged in three replications. The characters were falling number, gluten strengthand protein content, which were used to make multi-character the technological index of the industrial quality of the wheat grains and multi-character the technological index of the industrial quality of the wheat grains. Multi-character selection can be a useful tool for identifying genotypes and growing environments that maximize the industrial quality of wheat grain. The GGE method provides greater explicability of the effects of genotype $\mathrm{x}$ environment interaction based on multi-character selection. The multicharacter genetic approach predicted for the 
selection of the industrial quality of wheat grain results in reliable inferences in the indication of adaptability and stability for the AMMI method and for GGE.

Key words: Restricted maximum likelihood; Best linear unbiased prediction; AMMI; GGE; Selection index

\section{INTRODUCTION}

There are many factors influencing wheat production dynamics, among them, the intrinsic genetic characteristics of each genotype, the edaphoclimatic attributes of growing environment, and the aspects related to genotype $\mathrm{x}$ environment interaction ( $\mathrm{G} \mathrm{X} \mathrm{E}$ ) (Woyann et al., 2016). Therefore, a detailed study is necessary to estimate what cause the phenotypic variation in the character of interest, as well to define macro-environments, phenotypic stability and genotype-specific adaptability to favorable or unfavorable environments (Szareski et al., 2017).

Many biometric tools are available to estimate and define the best genotypes and growing environments, however, there is a need to search methods that best represent the effects of the G x E interaction. In that case, the Additive Main Effects and Multiplicative Interaction method (AMMI) allows to obtain joint estimates of the additive and multiplicative effects of the model, as well to represent the estimates related to the variation factors and magnitude of the character of interest through a biplot graph (Zobel, 1988). The Genotype Main Effects and Genotype Environment Interaction method (GGE) allows conjugating the effects linked to the genotypes, to the growing environments and those connected to the $\mathrm{G} \times \mathrm{E}$ interaction. It presents the genotypes that show high performance, as well to form a trigonometric arrangement to demonstrate which environments have superior behavior (Yan, 2000).

Since the industrial quality of wheat is determined by several characters of agronomic interest, such as gluten strength, which defines the bread-making quality, the falling number indicating the action intensity of the alpha-amylase enzyme and the protein content, which brings together the soluble fraction of the albumins and globulins, as well as, insoluble through gliadins and glutenins. Under these conditions, genotypes do not need to be select by only one of these characters in isolation, but it is possible to obtain a single trend through the multi-character approach, making selection efficient and reliable. This will allow to understand the phenotypic variations and the genetic effects that determine the industrial quality of the wheat grains. In this context, the objective of the work was to apply a genetic and phenotypic multi-character approach predicted to the use of the multivariate methods AMMI and GGE.

\section{MATERIAL AND METHODS}

The experiment was carried out in the agricultural crop year of 2016, during which five wheat genotypes were grown in 14 environments in the state of Rio Grande do Sul, Brazil (Table 1). The experimental design was a randomized block design, with 14 growing environments $\mathrm{x}$ five wheat genotypes arranged in three replications. 
Table 1. Description of growing environments (geographical coordinates, altitude, soil type, growing season I: second half of May 2016, growing season II: second half of June 2016) and wheat genotypes used to investigate the industrial quality of the wheat grain.

\begin{tabular}{|c|c|c|c|c|c|}
\hline Initials & Season & Environments & Coordinates & Altitude & Soil type* \\
\hline $\mathrm{E}_{1}$ & I & São Luiz Gonzaga-RS & $28^{\circ} 24^{\prime} 42^{\prime \prime} \mathrm{S}$ and $54^{\circ} 45^{\prime} 45^{\prime \prime} \mathrm{W}$ & $270 \mathrm{~m}$ & Dystrophic Red Latosol \\
\hline $\mathrm{E}_{2}$ & II & São Luiz Gonzaga-RS & $28^{\circ} 24^{\prime} 42^{\prime \prime} \mathrm{S}$ and $54^{\circ} 45^{\prime} 45^{\prime \prime} \mathrm{W}$ & $270 \mathrm{~m}$ & Dystrophic Red Latosol \\
\hline $\mathrm{E}_{3}$ & I & Santo Augusto-RS & $27^{\circ} 54^{\prime} 47^{\prime \prime} \mathrm{S}$ and $53^{\circ} 49^{\prime} 04^{\prime \prime} \mathrm{W}$ & $503 \mathrm{~m}$ & Dystroferric Red Latosol \\
\hline $\mathrm{E}_{4}$ & II & Santo Augusto-RS & $27^{\circ} 54^{\prime} 47^{\prime \prime} \mathrm{S}$ and $53^{\circ} 49^{\prime} 04^{\prime \prime} \mathrm{W}$ & $503 \mathrm{~m}$ & Dystroferric Red Latosol \\
\hline $\mathrm{E}_{5}$ & I & Cruz Alta-RS & $28^{\circ} 38^{\prime} 19^{\prime \prime} \mathrm{S}$ and $53^{\circ} 36^{\prime} 23^{\prime \prime} \mathrm{W}$ & $452 \mathrm{~m}$ & Dystrophic Red Latosol \\
\hline $\mathrm{E}_{6}$ & II & Cruz Alta-RS & $28^{\circ} 38^{\prime} 19^{\prime \prime} \mathrm{S}$ and $53^{\circ} 36^{\prime} 23^{\prime \prime} \mathrm{W}$ & $452 \mathrm{~m}$ & Dystrophic Red Latosol \\
\hline $\mathrm{E}_{7}$ & $\mathrm{I}$ & Cachoeira do Sul-RS & $30^{\circ} 17^{\prime} 52^{\prime \prime} \mathrm{S}$ and $52^{\circ} 57^{\prime} 54^{\prime \prime} \mathrm{W}$ & $113 \mathrm{~m}$ & Eutrophic Haplic Planosol \\
\hline $\mathrm{E}_{8}$ & II & Cachoeira do Sul-RS & $30^{\circ} 17^{\prime} 52^{\prime \prime} \mathrm{S}$ and $52^{\circ} 57^{\prime} 54^{\prime \prime} \mathrm{W}$ & $113 \mathrm{~m}$ & Eutrophic Haplic Planosol \\
\hline $\mathrm{E}_{9}$ & I & Vacaria-RS & $28^{\circ} 30^{\prime} 44^{\prime \prime} \mathrm{S}$ and $50^{\circ} 56^{\prime} 02^{\prime \prime} \mathrm{W}$ & $971 \mathrm{~m}$ & Aluminic Latosol \\
\hline $\mathrm{E}_{10}$ & II & Vacaria-RS & $28^{\circ} 30^{\prime} 44^{\prime \prime} \mathrm{S}$ and $50^{\circ} 56^{\prime} 02^{\prime \prime} \mathrm{W}$ & $971 \mathrm{~m}$ & Aluminic Latosol \\
\hline$E_{11}$ & $\mathrm{I}$ & Passo Fundo-RS & $28^{\circ} 13^{\prime} 17^{\prime \prime} \mathrm{S}$ and $52^{\circ} 19^{\prime} 39^{\prime \prime} \mathrm{W}$ & $709 \mathrm{~m}$ & Dystrophic Red Latosol \\
\hline$E_{12}$ & II & Passo Fundo-RS & $28^{\circ} 13^{\prime} 17^{\prime \prime} \mathrm{S}$ and $52^{\circ} 19^{\prime} 39^{\prime \prime} \mathrm{W}$ & $709 \mathrm{~m}$ & Dystrophic Red Latosol \\
\hline$E_{13}$ & I & São Gabriel-RS & $30^{\circ} 20^{\prime} 09^{\prime \prime} \mathrm{S}$ and $54^{\circ} 10^{\prime} 21^{\prime \prime} \mathrm{W}$ & $159 \mathrm{~m}$ & Eutrophic Haplic Planosol \\
\hline$E_{14}$ & II & São Gabriel-RS & $30^{\circ} 20^{\prime} 09 " \mathrm{~S}$ and $54^{\circ} 10^{\prime} 21$ '” & $159 \mathrm{~m}$ & Eutrophic Haplic Planosol \\
\hline & \multicolumn{5}{|c|}{ Genotypes } \\
\hline $\mathrm{G}_{1}$ & \multicolumn{5}{|c|}{ BRS Parrudo (breeder, EMBRAPA) } \\
\hline $\mathrm{G}_{2}$ & \multicolumn{5}{|c|}{ ORS 1403 (breeder, OR MELHORAMENTO) } \\
\hline $\mathrm{G}_{3}$ & \multicolumn{5}{|c|}{ LGORO (breeder, LIMAGRAIN BRASIL S/A) } \\
\hline $\mathrm{G}_{4}$ & \multicolumn{5}{|c|}{ TBIO Sinuelo (breeder, BIOTRIGO GENÉTICA) } \\
\hline $\mathrm{G}_{5}$ & \multicolumn{5}{|c|}{ Mirante (breeders, BIOTRIGO GENÉTICA/ OR MELHORAMENTO) } \\
\hline
\end{tabular}

The experimental units consisted of five sowing rows spaced by 0.20 meters and five meters in length. The sowing in growing environments was conducted during season I for the second half of May 2016 and season II is related to the second half of June 2016. The standard population density used was 330 viable seeds per square meter. The nutritional management was constituted by $250 \mathrm{~kg} \cdot \mathrm{ha}^{-1}$ of NPK in the formulation $08-25-20$ at the base fertilization and $50 \mathrm{~kg} \cdot \mathrm{ha}^{-1}$ of nitrogen for top-dressing at the full tillering stage in the form of urea ( $46 \%$ nitrogen).

After the harvest, the grains were submitted to the measurement of the determining attributes for the industrial quality. The samples were homogenized and cleaned, after each of them were conditioned to $15 \%$ moisture and rested for $12 \mathrm{~h}$. The grinding of the grains was realized in a Chopin pilot mill (model CD1 França ${ }^{\circledR}$ ) based on method no. 26-10 (AACCI, 2010). The obtained flour was submitted to measurement of the following characters:

Falling Number (FN): obtained by means of the Falling Number apparatus following method 56-81B (AACCI, 2010), results expressed in second (s).

Gluten strength $(\mathrm{W})$ : measured by Glutomatic apparatus, where procedures were based on method no. 38-12A (AACCI, 2010), results expressed in $10^{-4}$ Joules $\left(10^{-4} \mathrm{~J}\right.$ ).

Protein content (PTN): was measured by near infrared spectroscopy (NIR), results expressed in percentage $(\%)$.

The data were submitted to the analysis of individual variance for each growing environment, in order to verify the fulfillment of the assumptions of the model (Ramalho et al., 2012). Subsequently, the joint analysis was carried out with the purpose of identifying the interaction between the crop environments $x$ wheat genotypes at 0.05 probability. Due 
to the attributes of the industrial quality of the wheat grains, they showed a similar economic importance, they were combined in a multi-character index in order to show a unique tendency (Nunes et al., 2017).

This multi-character was denominated the technological index of the industrial quality of the wheat grains (TIIQ), being obtained by the following equation (a):

$$
\mathrm{TIIQ}=\left(\left(\frac{\mathrm{FN}}{\mathrm{S}_{\mathrm{FN}}}\right) \times\left(\frac{\mathrm{W}}{\mathrm{S}_{\mathrm{W}}}\right) \times\left(\frac{\mathrm{PTN}}{\mathrm{S}_{\mathrm{PTN}}}\right)\right)
$$

where: TIIQ: refers to the technological index of industrial quality of wheat grains, FN: corresponds to the observed value of the number of falls, W: corresponds to the observed value of the gluten strength, PTN: corresponds to the observed value of the protein content, $\mathrm{S}_{\mathrm{FN}}$ : refers to the standard deviation of the character $\mathrm{FN}, \mathrm{S}_{\mathrm{W}}$ : refers to the standard deviation of the character W, S STN: refers to the standard deviation of the PTN character.

The data were submitted to the method based on the Restricted Maximum Likelihood (REML) in order to obtain the components of variance and the genetic parameters, the significance was based on the Deviance analysis at 0.05 of probability by the chi-square test (Resende, 2007). For this, it was used the statistical model

$$
Y=X r+Z g+W i+e
$$

where: $y$ : is the data vector, $r$ : are the effects of (fixed) repetitions, $g$ : are genotypic (random) effects, $i$ : are the effects of interaction genotypes $\mathrm{x}$ environments (random), $e$ : are the (random) residues. It was estimated the genotype variance $\left(\sigma_{G}^{2}\right)$, variance of the interaction genotypes $\mathrm{x}$ environments $\left(\sigma_{I N T}^{2}\right)$, phenotype variance $\left(\sigma_{F}^{2}\right)$, heritability with broad sense of the genotype average $\left(\hat{h}^{2} m g\right)$, accuracy for the selection of genotypes $(\check{r} g \check{g})$, determination coefficient of the genotype $\mathrm{x}$ environment interaction effects $\left(C^{2}{ }_{I N T}\right)$, genotype correlation among environments performance $(\check{r}$ gloc), genotype coefficient of variation $(\mathrm{CVg})$, coefficient of residual variation $(\mathrm{CVe})$ and general mean of characters.

The components of variance and genetic parameters served as support to apply the Best Linear Unbiased Predictor (BLUP) methodology, where the predicted genetic value of the attributes concerning the industrial quality of the wheat grains was obtained. The predicted genetic values were used to make a multi-character called Predicted Genetic Index of Industrial Quality of Wheat Grains (PGIIQ), which is obtained by the following equation (b):

$$
\mathrm{PGIIQ}=\left(\left(\frac{\mathrm{GVP}_{F N}}{\mathrm{~S}_{\mathrm{GVP}_{\mathrm{FN}}}}\right) \times\left(\frac{\mathrm{GVPW}}{\mathrm{S}_{\mathrm{GVPW}_{\mathrm{W}}}}\right) \times\left(\frac{\mathrm{GVP}_{\mathrm{PTN}}}{\mathrm{S}_{\mathrm{GVP}_{\mathrm{PTN}}}}\right)\right)
$$

where: PGIIQ: refers to the Predicted Genetic Index of Industrial Quality of Wheat Grains , $\mathrm{GVP}_{\mathrm{FN}}$ : corresponds to the genetic value predicted for the falling number character, $\mathrm{GVP}_{\mathrm{W}}$ : corresponds to the predicted genetic value for the gluten force character, GVP $\mathrm{PTN}_{\mathrm{W}}$ : corresponds to the predicted genetic value for the character protein content, $\mathrm{SGVP}_{\mathrm{FN}}$ : refers to the standard deviation of the genetic value predicted for the character FN, SGVP to the standard deviation of the genetic value predicted for the character $\mathrm{W}, \mathrm{SGVP}_{\mathrm{PTN}}$ : the standard deviation of the genetic value predicted for the PTN character.

The technological index of the industrial quality of wheat grains (TIIQ) and the predicted genetic index of industrial quality of wheat grains (PGIIQ) were submitted to the verification of the model assumptions, where was realized the interaction between the crop 
environments $\mathrm{x}$ wheat genotypes at $5 \%$ of probability. Subsequently, estimates of the adaptability and stability were used by the AMMI and GGE approaches.

The AMMI method combines the main effects on genotypes and growing environments as well as the simple effects attributed to $\mathrm{G} \times \mathrm{E}$ interaction (Zobel et al., 1988). The multivariate model used was based on:

$$
Y_{i j}=\mu+g_{i}+e_{j}+\Sigma_{k=1}^{n} \lambda_{k} \gamma_{i k} \alpha_{j k}+\rho_{i j}+\varepsilon_{i j}
$$

where: $Y i j$ : represents the repetitions mean response of the $i^{\text {th }}$ genotype $(i)$ in the jth growing environment $(j) ; \mu$ : corresponds to the general average of the genotypes in the growing environments; $g i$ : appears as the main effect attributed to genotype $i$; $a j$ : represents the main effect of the growing environment $j ; \lambda k$, yik and $\alpha j k$ : correspond to the terms referring to the decomposition of the matrix $\mathrm{G} \times \mathrm{E}$ that captures the pattern associated with the interaction of genotype $i$ with the growing environment $j$, weights the additive deviations of the character of interest $(Y i j)$ in relation to the main effects of $g i$ and $a j$; $\rho i j$ : represents the noise that will be eliminated from the analysis concerning the interaction $\mathrm{G} \mathrm{x}$ E; $\varepsilon i j$ : corresponds to the experimental error (Duarte and Vencovsky, 1999).

The GGE method combines the effects attributed to the genotypes tested and those of the G $\mathrm{x}$ E interaction (Yan et al., 2000). It allows the identification of the genotype with high performance being efficient in a certain growing environment, in the same way, allows the formation of mega-environments (Woyann et al., 2016). The multivariate model used was based on:

$$
\mathrm{Y}_{\mathrm{ij}}-\mu-\beta_{\mathrm{j}}=\lambda_{1} \xi_{1 \mathrm{j}} \mathrm{n}_{1 \mathrm{j}}+\lambda_{2} \xi_{2 \mathrm{j}} \mathrm{n}_{2 \mathrm{j}}+\varepsilon_{\mathrm{ij}}
$$

where: $Y i j$ : represents the expected magnitude of the genotype $i$ cultivated in environment $j$; $\mu$ : corresponds to the overall mean of the observations $Y i j ; \beta j$ : is evidenced as the main effect attributed to the growing environment $j ; \lambda 1$ and $\lambda 2$ : correspond to the main scores (PC I) and secondary (PC II) determinants for the graphic expression through the main biplot components; $\xi 1 j$ and $\xi 2 j$ : are evidenced as the eigenvectors representing genotype $i$ in the $\mathrm{x}$ axes of PC I and PC II; $\varepsilon i j$ : expresses the unadjusted residue of the effects of the statistical model. Statistical Analysis System ${ }^{\circledR}$ (SAS, 1989), Genes (Cruz, 2013), R (R Core Team, $2015 \AA$ ) and Selegen (Resende, 2007) softwares were used to make the statistical analyses.

\section{RESULTS AND DISCUSSION}

\section{Components of variance and genetic parameters}

The Deviance analysis revealed significance at $5 \%$ of probability by the chi-square test $\left(\mathrm{X}^{2}\right)$ for the estimates of variance components and genetic parameters obtained by the restricted maximum likelihood method (REML), showing that the inferences made for the falling number $(\mathrm{FN})$, gluten strength $(\mathrm{W})$ and protein content in wheat flour were consistent and reliable. In this context, the phenotypic manifestation of the falling number character (FN) was controlled by $7.61 \%$ due to the genetic effects $\left(\sigma^{2}\right)$, the $\mathrm{G} \times \mathrm{E}$ interaction $\left(\sigma^{2} \mathrm{INT}\right)$ contributed with $11.02 \%$ in the phenotypic magnitude, being confirmed that the falling number (FN) of wheat flour is affected by more than $90 \%$ of actions imposed by the events linked to the growing environments (Table 2), these effects were confirmed by the magnitude of heritability with a broad sense $\left(\hat{\mathrm{h}}^{2}{ }_{\mathrm{mg}}\right)$. 
Table 2. Estimation of variance components and genetic parameters (REML) for the five wheat genotypes grown in 14 growing environments, where the falling number (FN), gluten strength $(\mathrm{W})$ and protein content (PTN) in wheat flour were assessed.

\begin{tabular}{lccc}
\hline Variance componentes and genetic parameters & Falling number $(\mathbf{F N}, \mathbf{s})$ & Gluten strength $\left(\mathbf{W}, \mathbf{1 0}^{-4} \mathbf{J}\right)$ & Protein $(\mathbf{P T N}, \boldsymbol{\%})$ \\
\hline$\sigma_{\mathrm{F}}^{2}$ & 333.776 & 2585.491 & 1.434 \\
$\sigma_{\mathrm{G}}^{2}$ & 0.254 & 171.520 & 0.814 \\
$\sigma_{\mathrm{INT}}^{2}$ & 36.792 & 285.179 & 0.290 \\
$\hat{h}^{2}{ }_{m g}$ & 0.031 & 0.746 & 0.968 \\
$\mathrm{rgg}$ & 0.176 & 0.863 & 0.984 \\
$\mathrm{C}^{2} \mathrm{INT}$ & 0.110 & 0.110 & 0.202 \\
$\mathrm{rgloc}$ & 0.006 & 0.375 & 0.736 \\
$\mathrm{CVg}(\%)$ & 0.146 & 3.957 & 6.486 \\
$\mathrm{CVe}(\%)$ & 5.018 & 13.943 & 4.130 \\
Overall mean & 343.266 & 330.89 & 13.910 \\
\hline$\sigma_{F}^{2}$ (phenotypic variance); $\sigma_{G}^{2}$ (genotypic variance); $\sigma_{\text {INT }}^{2}$ (variance of genotype x environment interaction); $\hat{h}^{2}{ }_{m g}$ \\
(heritability of the genotype mean, assuming complete survival); rgg (accuracy of genotype selection, assuming \\
complete survival); $C^{2}{ }_{I N T}$ (coefficient of determination of the effects of genotype x environment interaction); rgloc \\
(genotypic correlation between performance in various environments); CVg (\%) (genotypic coefficient of variation); \\
CVe (\%) (coefficient of residual variation).
\end{tabular}

In relation to the gluten strength $(\mathrm{W})$ the genetic effects $\left(\sigma_{G}^{2}\right)$ contributed with $6.63 \%$ for the phenotypic expression of the character $\left(\sigma_{F}^{2}\right)$. The differential effects of the $\mathrm{G} \times \mathrm{E}$ interaction $\left(\sigma_{I N T}^{2}\right)$ influenced in $11.03 \%$ the gluten strength of the wheat flour, in contrast, it is verified that this character is determined by $25.54 \%$ due to the edaphoclimatic characteristics of the growing environment, being this phenomenon proven by the magnitude of heritability with wide sense $\left(\hat{h}_{m g}^{2}\right)$. The protein content (PTN) contained in wheat flour $\left(\sigma_{F}^{2}\right)$ was determined by $56.76 \%$ due to the intrinsic genetic peculiarities $\left(\sigma_{G}^{2}\right)$ of the wheat genotypes, in the same way, these were influenced by $20.22 \%$ due to the manifestation of the $\mathrm{G} \times \mathrm{E}$ interaction $\left(\sigma_{I N T}^{2}\right)$. Compared to the measured traits that represent the wheat industrial quality, the protein content of the flour is classified as the character with greater heritability with a broad sense $\left(\hat{h}^{2}{ }_{m g}\right)$, proving that its phenotypic magnitude was affected by only $3.20 \%$ of the effects attributed to the environment.

The genotypic correlation for genotype performance among growing environments $(\check{r} g \check{g})$ makes it possible to define the nature of the $\mathrm{G} x \mathrm{E}$ interaction, whether simple or complex. So, a high magnitude for these parameters indicates that the nature of the $\mathrm{G} \times \mathrm{E}$ interaction is simple, where the genetic effects contribute in a superior way to the phenotypic manifestation of the character and consequently, there will be smaller distortions in the classification of the genotypes compared to the tested environments. However, when the genotypic correlation is low it becomes an indicative that the $\mathrm{G} \times \mathrm{E}$ interaction express complex nature, where it may hinder the selection and positioning of genotypes in the tested environments (Carvalho et al., 2017a). Under these conditions, the falling number $(\check{r} g \check{g}=0.006)(\mathrm{FN})$ and gluten strength $(\check{r} g \check{g}=0.375)$ (W) were obtained and, consequently, for these traits, the nature of the interaction was classified as complex. However, the protein content $(\check{r} g \check{g}=0.736)(\mathrm{PTN})$ showed a high coefficient where it proves that the $\mathrm{G} \times \mathrm{E}$ interaction revealed for this character has simple nature with low distortions in the phenotypic manifestation due to the effects of the environments (Table 2), this behavior favors genotypes with broad adaptability and or phenotypic stability.

Regarding the accuracy of the selection of the genotypes ( $\check{r} g l o c)$, it was observed that the estimates are highly accurate for the traits of gluten strength (W) and the protein content (PTN) contained in wheat flour. According to the coefficient of determination of the $\mathrm{G} \times \mathrm{E}$ 
interaction effects $\left(C^{2}{ }_{I N T}\right)$, it isan indicative that the phenomena was determinant for the total phenotypic variation of the falling number $(\mathrm{FN})$ and gluten strength $(\mathrm{W})$. The genotypic coefficient of variation $(\mathrm{CVg})$ makes possible to quantify the percentage of the variation resulting from the genetic effects, where the minimum magnitudes of this parameter were observed for the falling number (FN), this behavior is due to the high effect that the growing environment exerts on this character. On the other hand, the gluten strength (W) and the protein content (PTN) contained in the wheat flour expressed genetic variability. In relation to the coefficient of residual variation $(\mathrm{CVe})$ it was observed that for all the characters the magnitude of this parameter was low, however, the ratio $(\mathrm{CVg} / \mathrm{CVe}=1.08)$ between the $\mathrm{CVg}$ and $\mathrm{CVe}$ coefficients shows that only the protein content expressed sufficient genetic variability to cast a genotype as genetically superior. Research has shown that the ratio of these coefficients when greater than or equal to the unity, there is the predominance of genetic effects in the manifestation of the character with possibility of success in the selection using this character (Vencovsky, 1987; Carvalho et al., 2017b).

\section{Additive Main effects and Multiplicative Interaction (AMMI)}

\section{Phenotypic multi-character approach}

In order to contextualize this biometric scenario, the technological index of the industrial quality of the wheat grains (TIIQ) was used to represent the unique tendency of the falling number (FN), gluten strength (W) and protein content contained in the flour of five wheat genotypes grown in 14 environments. This multi-character was submitted to the AMMI method (Table 3; Figure 1). It makes possible to represent, together, the effects of the genotype, the environment and the $\mathrm{G} \times \mathrm{E}$ interaction. The simultaneity of the sources of variation allows inferring about the adaptability and the stability of the genotypes. In the same way, the effects are represented by axes denominated EPCA, which has the purpose of explaining the total variation attributed to the character of interest and also maximize the representativity of the standard fraction of the data and minimize the residual sources not explainable by the biometric model (Oliveira et al., 2003).

Due to the presence of interaction among growing environments $\mathrm{x}$ wheat genotypes at $5 \%$ of probability for the technological index of the industrial quality ofthe wheat grains (TIIQ), estimates were made by the AMMI method, which obtained $37.1 \%$ of explicability of the G $\mathrm{E}$ interaction through the first significant axis (EPCA I). In this way, the obtained scores defined the growing environments São Gabriel - RS season I (E13), Cruz Alta - RS season I (E5), Passo

Fundo - RS season I (E11), Vacaria - RS season I (E9), Vacaria - RS season II (E10), São Gabriel - RS season II (E14) and Santo Augusto - RS season I (E3) as stable.

When showing the cultivation environments with higher magnitudes than the general average (TIIQ), it was observed that genotypes BRS Parrudo (G1) presented specific adaptability to the environments Passo Fundo - RS season II (E12) and Santo Augusto - RS season I (E3).Also, it was verified that genotypes LGORO (G3) and TBIO Sinuelo evidenced specific adaptability to the growing environment of Santo Augusto - RS season II (E4). The genotypes ORS 1403 and Mirante did not adjust to any specific environment and both are inferior to the general average.

\section{Predicted genetic multi-character approach}


The understanding of the predicted multi-character genetic approach was possible through the Predicted Genetic Index of Industrial Quality of Wheat Grains (PGIIQ), which expressed significant interaction among the growing environments $\mathrm{x}$ wheat genotypes at $5 \%$ of probability. The AMMI method made it possible to explain $40.33 \%$ of the differential effects of $\mathrm{G} \times \mathrm{E}$ interaction through the representativeness of EPCA I (Table 3, Figure 2). By obtaining the scores, it was possible to indicate that the growing environments Vacaria - RS season I (E9), São Gabriel - RS season I (E13), São Gabriel - RS season II (E14), Cachoeira do Sul - RS season II (E8), Cruz Alta - RS season I (E5), Santo Augusto - RS season I (E3), Passo Fundo - RS season I (E11) and São Luiz Gonzaga - RS season I (E1) were considered stable. When showing the growing environments with magnitudes above the general average (PGIIQ), it was observed that the genotype BRS Parrudo (G1) presented specific adaptability to the environments of São Luiz Gonzaga-RS season I (E1), Santo Augusto - RS season I (E3), Cruz Alta - RS season I (E5) and Passo Fundo - RS apoch II (E12). Specific adaptability of the genotypes LGORO and TBIO Sinuelo were expressed to the growing environment of Santo Augusto - RS season II (E4), but these levels of the variation factors contributed with negative scores to the effects of genotypes $\mathrm{x}$ environments interaction. The genotypes Mirante (G5) and ORS 1403 (G2) together with the growing environment São Luiz Gonzaga - RS season II (E2) did not allow specific inferences to be made in this approach.

Table 3. Scores (EPCA) for the AMMI and GGE methods concerning the phenotypic approach (TIIQ) and predicted genetics (PGIIQ) applied in multi-character selection for the industrial quality of wheat grain.

\begin{tabular}{|c|c|c|c|c|c|c|c|}
\hline & & \multicolumn{2}{|l|}{ AMMI } & \multicolumn{4}{|l|}{ GGE } \\
\hline & & ITQI & IGPQI & ITQI & & IGPQI & \\
\hline & & EPCA I & EPCA I & EPCA I & EPCA II & EPCA I & EPCA II \\
\hline & & $37.10 \%$ & $40.30 \%$ & $62.90 \%$ & $17.50 \%$ & $85.20 \%$ & $7.10 \%$ \\
\hline \multicolumn{8}{|c|}{ Wheat genotypes } \\
\hline BRS Parrudo & $\mathrm{G}_{1}$ & 7.05 & 24.30 & 0.20 & 0.38 & 0.57 & -0.75 \\
\hline ORS 1403 & $\mathrm{G}_{2}$ & -12.29 & -29.31 & -0.27 & -0.44 & -0.87 & 0.89 \\
\hline LGORO & $\mathrm{G}_{3}$ & -2.69 & -4.26 & 0.28 & 0.00 & 0.68 & 0.13 \\
\hline TBIO Sinuelo & $\mathrm{G}_{4}$ & -5.51 & -5.21 & 0.42 & -0.15 & 1.26 & 0.23 \\
\hline Mirante & $\mathrm{G}_{5}$ & 13.44 & 14.49 & -0.63 & 0.21 & -1.64 & -0.50 \\
\hline \multicolumn{8}{|c|}{ Growing environments } \\
\hline SLG season I & $\mathrm{E}_{1}$ & 4.21 & 5.40 & 0.08 & 0.10 & 0.49 & -0.18 \\
\hline SLG season II & $\mathrm{E}_{2}$ & -13.02 & -34.85 & 0.23 & -0.43 & 0.56 & 1.09 \\
\hline SA season I & $\mathrm{E}_{3}$ & 3.66 & 4.65 & 0.10 & 0.00 & 0.56 & -0.14 \\
\hline SA season II & $\mathrm{E}_{4}$ & -5.17 & -4.79 & 0.17 & -0.19 & 0.72 & 0.17 \\
\hline CA season I & $\mathrm{E}_{5}$ & -0.58 & 3.68 & 0.21 & 0.00 & 0.61 & -0.12 \\
\hline CA season II & $\mathrm{E}_{6}$ & 4.44 & 8.91 & 0.28 & 0.21 & 0.73 & -0.27 \\
\hline CS season I & $\mathrm{E}_{7}$ & -3.40 & -6.27 & 0.24 & -0.05 & 0.50 & 0.17 \\
\hline CS season II & $\mathrm{E}_{8}$ & -5.00 & -2.46 & 0.38 & -0.08 & 0.83 & 0.11 \\
\hline VAC season I & $\mathrm{E}_{9}$ & 1.07 & 0.03 & 0.22 & 0.02 & 0.64 & 0.00 \\
\hline VAC season II & $\mathrm{E}_{10}$ & 1.18 & 7.85 & 0.36 & 0.19 & 0.77 & -0.23 \\
\hline PF season I & $\mathrm{E}_{11}$ & -0.82 & -2.31 & 0.12 & -0.03 & 0.54 & 0.06 \\
\hline PF season II & $\mathrm{E}_{12}$ & 11.18 & 13.63 & 0.03 & 0.26 & 0.53 & -0.43 \\
\hline SG season I & $\mathrm{E}_{13}$ & -0.28 & 1.86 & 0.34 & 0.07 & 0.85 & -0.02 \\
\hline SG season II & $\mathrm{E}_{14}$ & 2.53 & 4.65 & 0.16 & 0.04 & 0.51 & -0.15 \\
\hline
\end{tabular}

The genotypes were BRS Parrudo $\left(\mathrm{G}_{1}\right)$, ORS $1403\left(\mathrm{G}_{2}\right)$, LGORO $\left(\mathrm{G}_{3}\right)$, TBIO Sinuelo $\left(\mathrm{G}_{4}\right)$, and Mirante $\left(\mathrm{G}_{5}\right)$, grown in the environments São Luiz Gonzaga - RS season I $\left(E_{1}\right)$, São Luiz Gonzaga - RS seasonII $\left(E_{2}\right)$, Santo Augusto - RS season I ( $\left.\mathrm{E}_{3}\right)$, Santo Augusto - RS season II $\left(\mathrm{E}_{4}\right)$, Cruz Alta - RS season I ( $\left.\mathrm{E}_{5}\right)$, Cruz Alta - RS season II ( $\left.\mathrm{E}_{6}\right)$, Cachoeira do Sul - RS season I ( $\left.\mathrm{E}_{7}\right)$, Cachoeira do Sul - RS season II ( $\left.\mathrm{E}_{8}\right)$, Vacaria - RS season I $\left(\mathrm{E}_{9}\right)$, Vacaria - RS season II ( $\left.\mathrm{E}_{10}\right)$, Passo Fundo - RS seasonI ( $\left.E_{11}\right)$, Passo Fundo - RS season II ( $\left.E_{12}\right)$, São Gabriel - RS seasonI ( $\left.E_{13}\right)$ and São Gabriel - RS season II $\left(E_{14}\right)$, refering to the agricultural crop of 2016. 


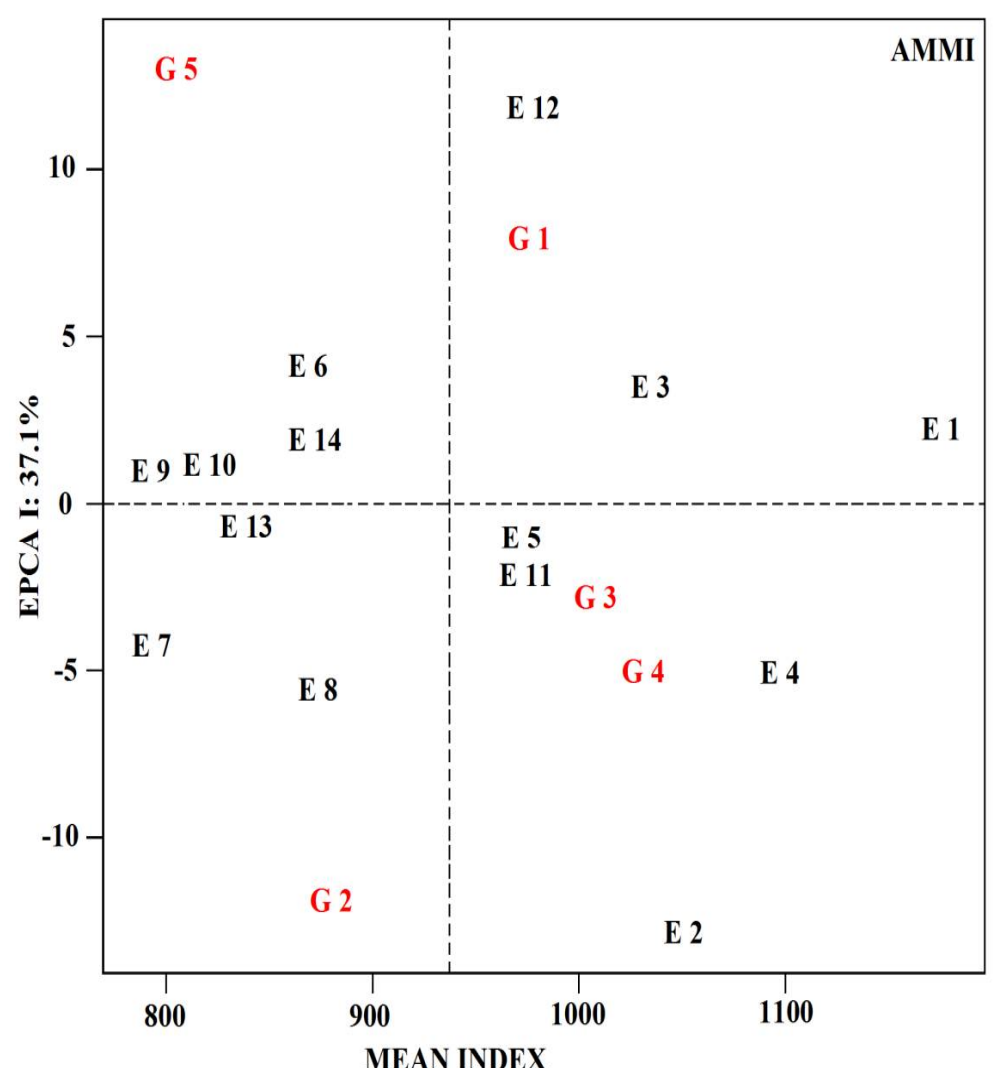

Figure 1. Additive main effects and multiplicative interaction (AMMI) method through the multi-factorial phenotypic approach by the technological index of the industrial quality of the wheat grains (TIIQ). The genotypes were BRS Parrudo (G1), ORS 1403 (G2), LGORO (G3), TBIO Sinuelo (G4), and Mirante (G5), grown in the environments São Luiz Gonzaga - RS season I (E1), São Luiz Gonzaga - RS season II (E2), Santo Augusto - RS season I (E3), Santo Augusto - RS season II (E4), Cruz Alta - RS season I (E5), Cruz Alta - RS season II (E6), Cachoeira do Sul - RS season I (E7), Cachoeira do Sul - RS season II (E8), Vacaria - RS season I (E9), Vacaria - RS season II (E10), Passo Fundo - RS season I (E11), Passo Fundo - RS season II (E12), São Gabriel RS season I (E13) and São Gabriel - RS season II (E14), referring to the agricultural crop of 2016.

\section{Genotype Main Effects and Genotype Environment Interaction (GGE)}

\section{Phenotypic multi-character approach}

In this scenario, the technological index of the industrial quality of the wheat grains (TIIQ) was applied to the GGE method with the purpose of obtaining the formation of the macro growing environments, to understand the superior performance of the genotypes and the trigonometric formation of the genotypes to contrast with the low or high-performance environments for multicarrier (Table 3, Figure 3). The method allowed to explain $80.40 \%$ of the effects of the $\mathrm{G} \times \mathrm{E}$ interaction, where it combined the effects of the abscissae axis PC I $(62.9 \%)$ and PC II (17.5\%). The definition of the macro-environments is based on those environments that are edaphoclimatically correlated, in this way, the method provided the formation of two macro-environments defined by the dashed red lines (Figure 3). 
The macro-environment I gathered $28.6 \%$ of the growing environments, being these, São Luiz Gonzaga - RS season I (E1), Cruz Alta - RS season II (E6), Vacaria - RS season II (E10) and Passo Fundo - RS season II (E12), where the trigonometric definition formed by the wheat genotypes showed that the growing environments Cruz Alta - RS season II (E6), Vacaria RS season II (E10) showed high performance. It was determined that $75 \%$ of the constituent environments of the macro-environment I are represented by the sowing season II (second half of June), under these conditions it is determined that the genotype BRS Parrudo presented specific adaptability and high performance for this multi-character.

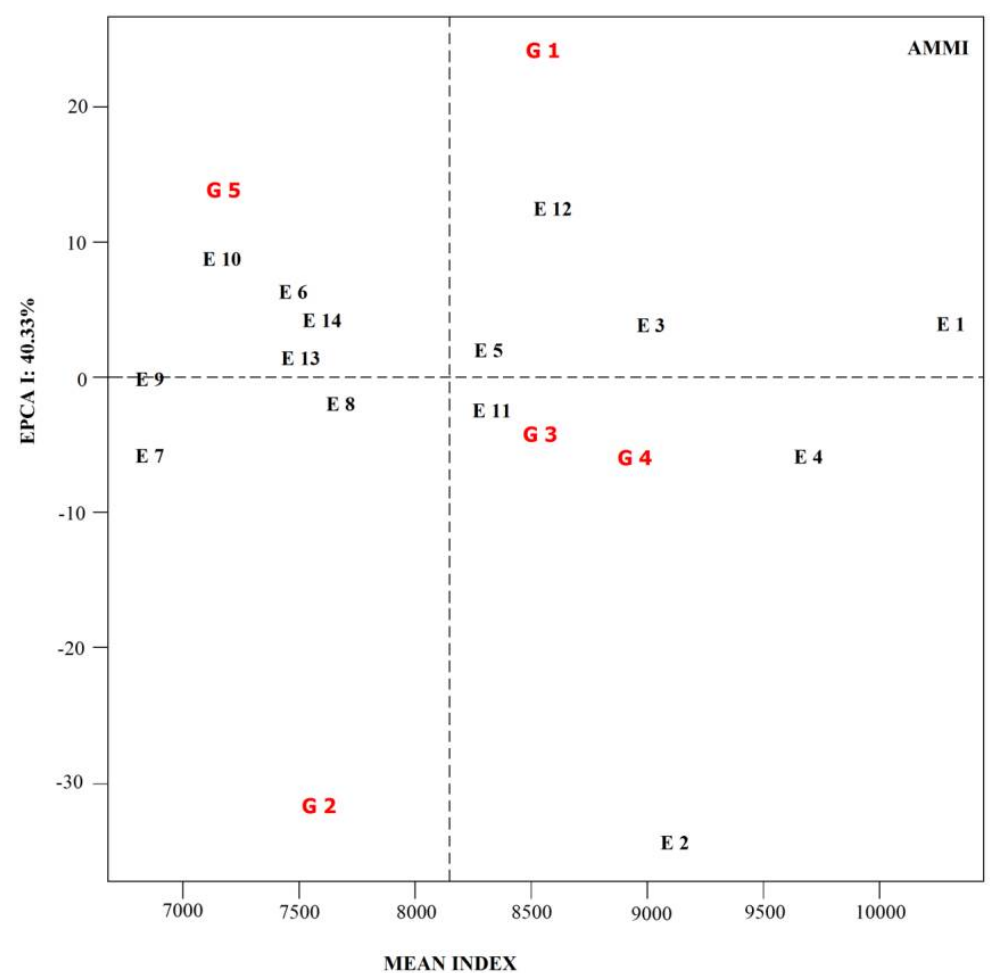

Figure 2. The Additive Main Effects and Multiplicative Interaction (AMMI) method through the genetic multicharacter approach predicted by the Predicted Genetic Index of Industrial Quality of Wheat Grains (PGIIQ). The genotypes BRS Parrudo (G1), ORS 1403 (G2), LGORO (G3), TBIO Sinuelo (G4), and Mirante (G5), grown in the environments São Luiz Gonzaga - RS season I (E1), São Luiz Gonzaga - RS season II (E2), Santo Augusto RS season I (E3), Santo Augusto - RS season II (E4), Cruz Alta - RS season I (E5), Cruz Alta - RS season II (E6), Cachoeira do Sul - RS season I (E7), Cachoeira do Sul - RS season II (E8), Vacaria - RS season I (E9), Vacaria RS season II (E10), Passo Fundo - RS season I (E11), Passo Fundo - RS season II (E12), São Gabriel - RS season I (E13) and São Gabriel - RS season II (E14), referring to agricultural crop 2016.

The macro-environment II was responsible for gathering $71.4 \%$ of the environments tested, being these: São Luiz Gonzaga - RS season II (E2), Santo Augusto - RS season I (E3), Santo Augusto - RS season II (E4), Cruz Alta - RS season I (E5), Cachoeira do Sul - RS season I (E7), Cachoeira do Sul - RS season II (E8), Vacaria - RS season I (E9), Passo Fundo - RS, season I (E11), São Gabriel - RS season I (E13) and São Gabriel - RS season II (E14). In this macro environment, environments above the polygon boundary are considered high performance, such as, São Luiz Gonzaga - RS season II (E2), Cachoeira do Sul - RS season II 
(E8) and São Gabriel - RS season I (E13 ), under these conditions 60\% of the environments were sown in the first sowing season corresponding to the first half of May. The genotypes with specific adaptability for this macro environment were the TBIO Sinuelo classified as high performance and LGORO. In this approach, it was not possible to infer about the indication of the genotypes ORS 1403 and Mirante, since, even these revealing high performance and contributing to the formation of the polygon, did not reveal specific affinity to any growing environment.

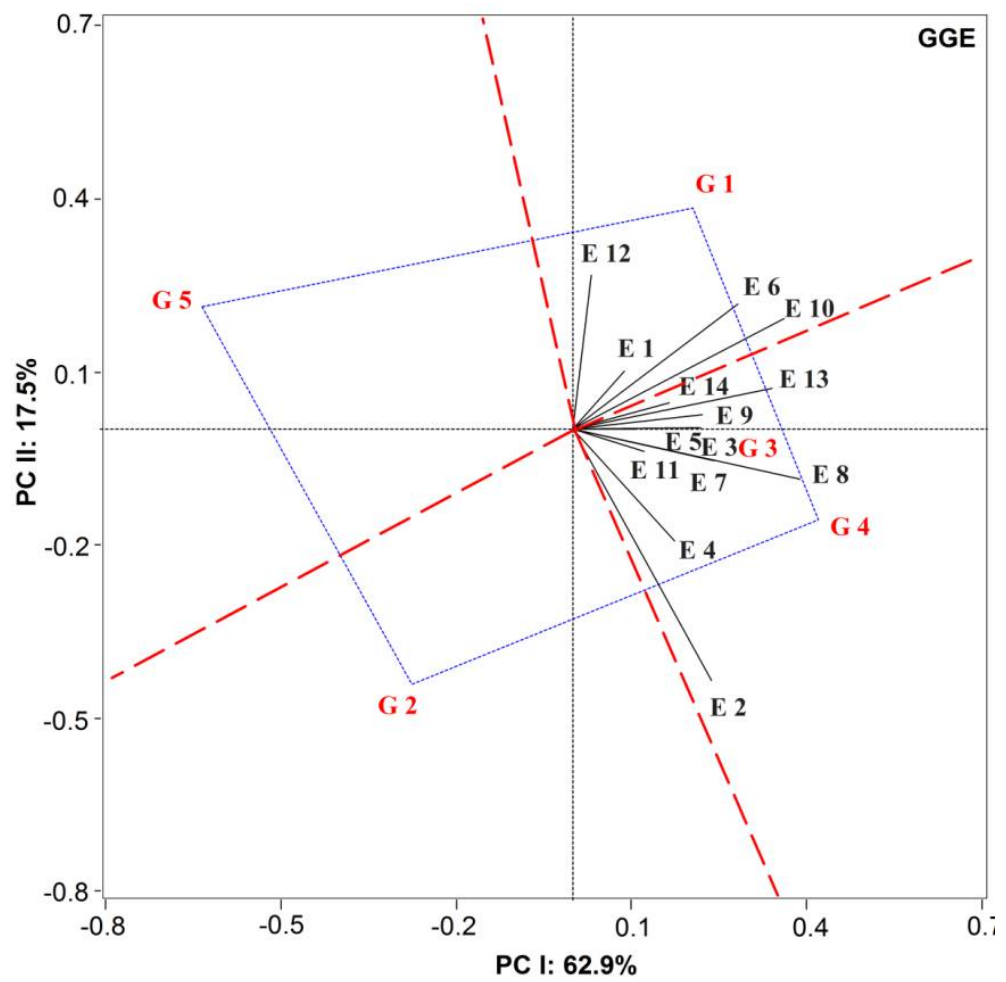

Figure 3. The Genotype Main Effects and Genotype Environment Interaction (GGE) method through the phenotypic multi-character approach by the technological index of the industrial quality of the wheat grains (TIIQ). Being the genotypes BRS Parrudo (G1), ORS 1403 (G2), LGORO (G3), TBIO Sinuelo (G4), and Mirante (G5), grown in the environments São Luiz Gonzaga - RS season I (E1), São Luiz Gonzaga - RS season II (E2), Santo Augusto - RS season I (E3), Santo Augusto - RS season II (E4), Cruz Alta - RS season I (E5), Cruz Alta - RS season II (E6), Cachoeira do Sul - RS season I (E7), Cachoeira do Sul - RS season II (E8), Vacaria - RS season I (E9), Vacaria - RS season II (E10), Passo Fundo - RS season I (E11), Passo Fundo - RS season II (E12), São Gabriel - RS season I (E13) and São Gabriel - RS season II (E14), referring to the agricultural crop of 2016.

\section{Predicted genetic multi-character approach}

In this context, the Predicted Genetic Index of Industrial Quality of Wheat Grains (PGIIQ) was used to the GGE method, where it was possible to represent $92.3 \%$ of the effects of the G x E interaction and to combine the effects of the axis of the abscissae PC I (85.2\%) and PC II $(7.1 \%)$. With the use of the predicted genetic multi-character, it was possible to identify the formation of two macro-environments (Table 3: Figure 4), with the macro-environment I being responsible for gathering $85.71 \%$ and the macro-environment II $14.29 \%$ of the growing 
environments tested. The macro-environment I was formed through the growing environments São Luiz Gonzaga - RS season II (E2), Santo Augusto - RS season I (E3), Santo Augusto - RS season II (E4), Cruz Alta - RS season I (E5), Cruz Alta - RS season II (E6), Cachoeira do Sul RS season I (E7), Cachoeira do Sul - RS season II (E8), Vacaria - RS season I (E9), Vacaria-RS season II (E10), Passo Fundo - RS season I (E11), São Gabriel - RS season I (E13) and São Gabriel - RS season II (E14).In this macro-environment high performance was conferred to environmentsSão Luiz Gonzaga - RS season II (E2), Santo Augusto - RS season II (E4), Cachoeira do Sul - RS season I (E7), Cachoeira do Sul - RS season II (E8), Vacaria - RS season I (E9), São Gabriel - RS season I (E13), Vacaria-RS season II (E10), Cruz Alta - RS season II (E6).It is evidenced that for these specific conditions adaptability was established for LGORO of high performance, TBIO Sinuelo and Mirante.

The macro-environment II gathered the environments São Luiz Gonzaga - RS season I (E1) and Passo Fundo - RS season II (E12), under these conditions it was not possible to obtain any environment with high performance, in contrast, the genotype BRS Parrudo showed specific adaptability to this macro-environment. The genotype ORS 1403 revealed high performance, however, showed no affinity with any of the environments tested.

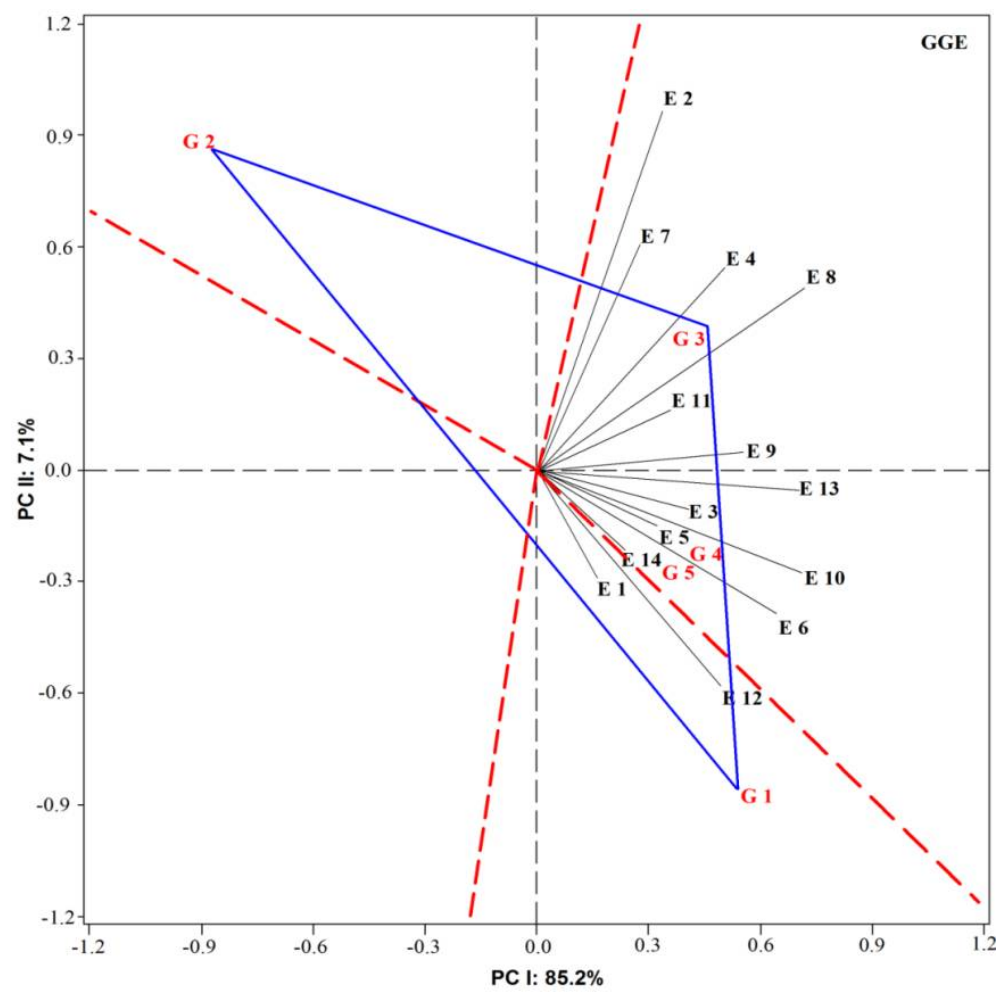

Figure 4. Genotype Main Effects and Genotype Environment Interaction (GGE) method through the genetic multicharacter approach predicted by the Predicted Genetic Index of Industrial Quality of Wheat Grains (PGIIQ). Being the genotypes BRS Parrudo (G1), ORS 1403 (G2), LGORO (G3), TBIO Sinuelo (G4), and Mirante (G5), grown in the environments São Luiz Gonzaga - RS season I (E1), São Luiz Gonzaga - RS season II (E2), Santo Augusto - RS season I (E3), Santo Augusto - RS season II (E4), Cruz Alta - RS season I (E5), Cruz Alta - RS season II (E6), Cachoeira do Sul - RS season I (E7), Cachoeira do Sul - RS season II (E8), Vacaria - RS season I (E9), Vacaria - RS season II (E10), Passo Fundo - RS season I (E11), Passo Fundo - RS season II (E12), São Gabriel - RS season I (E13) and São Gabriel RS season II (E14), referring to the agricultural crop year of 2016. 


\section{Phenotypic approach $\mathbf{x}$ predicted genetics}

In relation to the estimates obtained for the AMMI method, using the technological index of the industrial quality of the wheat grains (TIIQ) and the Predicted Genetic Index of Industrial Quality of Wheat Grains (PGIIQ), it was possible to observe that the use of the multivariate model based on the predicted genetic values (PGIIQ) increased the explainability of genotype $\mathrm{x}$ environment interaction in $3.23 \%$ (EPCA). Aiming the environments considered favorable and specific to certain genotypes, it is evident that the use of the Predicted Genetic Index of Industrial Quality of Wheat Grains (PGIIQ) increased by $7.1 \%$ the definition of favorable environments, in contrast, the phenotypic stability and the definition of unfavorable environments was similar for both the phenotypic approach (TIIQ) and the predicted genetic approach (PGIIQ).

The GGE method using the predicted genetic values (PGIIQ) increased by $11.9 \%$ the explanation of the differential effect regarding the $\mathrm{G} \times \mathrm{E}$ interaction. Both approaches (TIIQ and PGIIQ) defined two macro-environments, however, when using the predicted genetic approach results in $57.11 \%$ changes in the dynamics of indication of which growing environments should compose each macro-environment. In relation to genotypes defined as high performance, it was verified that the use of predicted genetic values (PGIIQ) minimizes the magnitude of genotypes necessary to define the vertices of the multivariate polygon and to improve the estimates in $21.40 \%$ in the definition of which are the environments of high performance.

For the multivariate methods of AMMI and GGE, it was observed that the predicted genetic approach (PGIIQ) is more promising than the phenotypic approach (TIIQ), since the GGE method using the predicted genetic values increased by $8.67 \%$ the explicability of the interaction genotypes x environments in relation to the AMMI method, in the same way, increased by $14.3 \%$ the efficiency in defining which were the favorable environments for the industrial quality of the wheat grains.

The AMMI method employing both the phenotypic (TIIQ) and predicted genetic (PGIIQ) approach defines the genotype BRS Parrudo (G1) as superior for the industrial quality of wheat grains, in contrast, the GGE method referring to the phenotypic approach (TIIQ) expressed similar response, but with the use of prediction (PGIIQ), the genotype LGORO (G3) was defined as superior. It was verified that, both approaches (phenotypic and genetic predicted) were efficient to define and explain the effects of the genotype $\mathrm{x}$ environment interaction for the industrial quality of the wheat grains. The genetic approach predicted was efficient in positioning wheat genotypes for many enviroments, higher for data phenotypic (Szareski et al., 2018). Thus, confirmed that the use of predicted genetic values (PGIIQ) applied to multivariate methods of adaptability and stability to a multicharacter approach was efficient and can provide reliable inferences that will aid the recommendation of the best genotypes and growing environments that maximize the industrial quality of the wheat grains.

\section{CONCLUSIONS}

Multi-character selection is efficient in identifying genotypes and growing environments that maximize the industrial quality of wheat produced in Brazil. The Genotype Main Effects and Genotype Environment Interaction method provides greater 
explicability of the effects of genotype $\mathrm{x}$ environment interaction based on multi-character selection.

The multicharacter genetic approach predicted for the selection for the industrial quality of wheat grains results in reliable inferences in the indication of adaptability and stability for the AMMI and GGE.

\section{ACKNOWLEDGMENTS}

The authors would like to thank the research funding agencies CAPES, CNPq and FAPERGS for the scholarships granted to the graduate students participating in the study.

\section{CONFLICTS OF INTEREST}

The authors declare no conflict of interest.

\section{REFERENCES}

AACCI. American Association of Cereal Chemists International (2010). Approved 445 Methods of Analysis (11th ed.). St Paul, MN, USA: AACC International.

Carvalho IR, Nardino M, Demari G, Pelegrin AJ, et al. (2017a). Components of variance and inter-relation of important traits to maize (Zea mays) breeding. Aust. J. Crop. Sci. 11: 982-988.

Carvalho IR, Pelegrin AJ, Szareski VJ, Ferrari M, et al. (2017b). Diallel and prediction (REML/BLUP) for yield components in intervarietal maize hybrids. Genet. Mol. Res. 16: gmr16039734. DOI:10.4238/gmr16039734

Cruz CD (2013). Genes - A software package for analysis in experimental statistics and quantitative genetics. Acta Sci. 35(3): 271-276. http://dx.doi.org/10.4025/actasciagron.v35i3.21251

Duarte JB and Vencovsky R (1990). Interação genótipo × ambiente: uma introdução à análise "AMMI". Sociedade Brasileira de Genética, Ribeirão Preto. 60 p.

Nunes ACP, Resende MDV, Santos GA and Alves RS (2017). Evaluation of different selection indices combining Pilodyn penetration and growth performance in Eucalyptus clones. Crop Breed. Appl. Biotechnol. 17: 206-213. http://dx.doi.org/10.1590/1984-70332017v17n3a32

Oliveira AB, Duarte JB and Pinheiro JB (2003). Emprego da análise AMMI na avaliação da estabilidade produtiva em soja. Pesq. Agropec. Bras. 38(3): 357-364, http://dx.doi.org/10.1590/S0100-204X2003000300004

R CORE TEAM (2015). R: A language and environment for statistical computing. R Foundation for Statistical Computing, Vienna, Austria.

Ramalho MAP, Ferreira DF and Oliveira AC (2012). Experimentation in genetics and plant breeding = Experimentação em genética e melhoramento de plantas. Lavras: UFLA, 2012. 326 p.

Resende MDV (2007). Software SELEGEN-REML/BLUP: Statistical system and computational genetic selection by linear mixed models $=$ Software SELEGEN-REML/BLUP: Sistema estatístico e seleção genética computadorizada via modelos lineares mistos. Colombo: Embrapa Florestas, 2007. 359 p.

Santos HG, Jacomine PKT, Anjos LHC, Oliveira VA, et al. (2013). Brazilian system of soil classification = Sistema brasileiro de classificação de solos. 3. ed. Brasília: Embrapa. 353 p.

SAS INSTITUTE (Cary, NC). (1989). SAS/STAT. User's Guide. GLMVARCOMP: version 6.4.ed. v.2, Cary, 846p.

Szareski VJ, Carvalho IR, Kehl K, Levien AM, et al. (2018). Phenotypic and predicted genetic approaches for genotype ranking of wheat seed yield in Brazil. Genet. Mol. Res. 17(3): gmr18026.

Szareski VJ, Carvalho IR, Kehl K, Levien AM, et al. (2017). Univariate, multivariate techniques and mixed models applied to the adaptability and stability of wheat in the Rio Grande do Sul State. Genet. Mol. Res. 16(3): gmr16039735. http://dx.doi.org/10.1590/s0100-204x2018000600009

Vencovsky R (1987). Herança quantitativa. In: Paterniani, E.; Viegas, G.P. Maize breeding and production = Melhoramento e produção do milho. 2. ed. Fundação Cargill, Campinas. p. 137-214.

Woyann LG, Benin G, Storck L, Trevizan DM, et al. (2016). Estimation of Missing Values Affects Important Aspects of GGE Biplot Analysis. Crop Sci. 57: 1-13.

Yan W, Hunt LA, Sheng Q and Szlavnics Z (2000). Cultivar evaluation and mega-environment investigation based on the GGE Biplot. Crop Sci. 40: 597-605.

Zobel RW, Wright MJ and Gauch Jr. HG (1998). Statistical analysis of a yield trial. Agron. J. 80: 388-393. 